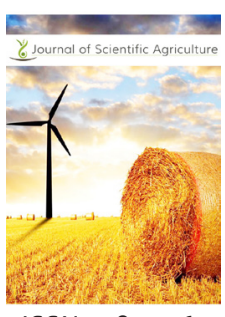

ISSN: 2184-0261

\title{
Assessment of indigenous knowledge of medicinal plants used for livestock treatment in five selected Kebeles of Kersa District, Jimma Zone, South Western Ethiopia
}

\author{
Emiru Chimdessa Gemechu* \\ Oromia Agricultural Research Institute, Adami Tulu Agricultural Research Center, PO.Box.35, Ziway, Ethiopia
}

\begin{abstract}
Plants have been as source of medicine in Ethiopia from time immemorial to treat different human and livestock ailments. The purpose of this study was to identify the medicinal plant species and associated indigenous knowledge in livestock treatment. A cross-sectional study was conducted to assess indigenous knowledge of local people on medicinal plants used for livestock treatment in five selected kebeles of kersa district from March to June 2014. A total of 40 traditional healers ( 33 male and 7 male) 7-9 from each study sites were selected purpouvely with the help of knowledgeable elders, local authorities and kebele leaders. Ethno botanical data regarding plant species, plant parts used, livestock disease treated, and method of preparation and route of administration were collected through structured interview and field observation. A total of 33 plant species distributed in 24 families were identified in the study area. The majority of the medicinal plants $63.63 \%$ were collected from the wild and $33.33 \%$ from home garden. The major growth habit of the medicinal plants identified in the study area were herbs $39.39 \%$, followed by shrubs $33.33 \%$. The most frequently harvested plant parts were leaves and roots with proportion of $57.7 \%$ and $21.21 \%$, respectively followed by seeds $(9.09 \%)$ and fruits $(6.06 \%)$. Pounding and crushing were the most commonly used method of remedies preparation where as the widely used method of administration is oral. The study reveals that the local people of the study area harvest medicinal plants used to treat livestock health problem from the wild habitat. Therefore, awaring the local people of the study area to conserve medicinal plants in their home garden is recommended.
\end{abstract}

Emiru Chimdessa Gemechu, E-mail: imiruchimdessa@gmail. com

KEYWORDS: Indigenous knowledge, Medicinal plant, Traditional healers, Traditional medicine

\section{INTRODUCTION}

In all countries of the world, there exists traditional knowledge related to the health of animals. In Africa, traditional healers and remedies made from plants play an important in the health of millions of animals (Rukangria, 2001), which is studied by ethno veterinary medicine. Ethiopia is leading in livestock population in Africa, with an estimated population of 43 million cattle, 2.3 million sheep, 18.6 goats, 17 million horse, 0.6 camels, and 34.2 million poultry, 4.5 million donkeys and 0.36 million mules (2006/7 CSA). However, livestock productivity is relatively poor owing to inadequate availability of feed, widespread diseases, poor health services and insufficient knowledge on the dynamics of the different farming systems in the country (Yirga and Hassen, 2000). Ethno veterinary medicine is frequently used for treatment of livestock diseases by many different ethnic groups in Ethiopia. Nearly $90 \%$ of livestock production in the country use plant based traditional medicine as their major health care system (Endashaw, 2007). Ethno veterinary medicine studies traditional knowledge, folk beliefs, skills, methods and practices used for treatment of livestock ailments (Tabuti et al., 2003). It offers medicines which are cheap and locally available than pharmacotherapy.

Because of the higher price of modern medicines and lack of accessibility to a modern veterinarian in the rural areas, farmers rely on traditional veterinary healers for treatment of livestock ailment (Harun-or- Rashid et al., 2010).In addition, they believe that the medicinal plants were more efficacious for treating of livestock ailments than modern medicine (Harunor- Rashid et al., 2010). Various researchers in Ethiopia have reported the loss of valuable medicinal plants due to population pressure, agriculture and deforestation (Abebe, 2001; Getachew and Shiferaw, 2002; Yirga, 2006). For generations, the ethno

Copyright: $\odot$ The authors. This article is open access and licensed under the terms of the Creative Commons Attribution License (http://creativecommons.org/licenses/by/4.0/) which permits unrestricted, use, distribution and reproduction in any medium, or format for any purpose, even commercially provided the work is properly cited. Attribution - You must give appropriate credit, provide a link to the license, and indicate if changes were made. 
veterinary practices to treat and control livestock diseases is an old practice in a large part of the world, particularly developing countries where animal health services are still very poor or land are found scarcely located at urban areas (Kokwaro,1976; McCorkle,1995; Sinha et al., 2002). In Ethiopia people have been using plant species for medication of different animal diseases over centuries when there was no modern health service delivery. The practice was not stopped with introduction of modern pharmacotherapy and plant remedies are still the most important and sometimes the only sources of therapeutics for nearly more than 90\% livestock population (Tadeg et al., 2005; Giday et al., 2009).

However, information on veterinary herbal medicine has not been systematically documented (Sori et al., 2004) and there is a danger that knowledge will soon be lost as traditional social patterns are increasingly disturbed by globalization (Giday et al., 2009), environmental degradation, agricultural expansion, cultivation of marginal lands and urbanization (Teklehaymanot \& Giday, 2007; Lulekal et al., 2008; Giday et al., 2009) warranting urgent need to document and preserve indigenous knowledge (Kalayou et al., 2012). Thus, there is a gap in the documentation and records on medicinal plants in all parts of Ethiopia including Kersa district, Jimma Zone,Oromia Region, South Western Ethiopia. Therefore, this study was conducted to assess and document medicinal plant species and associated indigenous knowledge in livestock treatment in the study area.

\section{MATERIALS AND METHODS}

\section{Study Area and Period}

The study was conducted in Kersa; one of the districts found in Jimma Zone, Oromia Region, and South Western Ethiopia from March to June 2014. Kersa is situated $18 \mathrm{~km}$ away to the North East of Jimma town and $328 \mathrm{~km}$ south west of Addis Ababa. The district is bounded by Limmu Kossa, TiroAfetta, Omonada and Manna Dedo to the North, East, West and South respectively. The district has 31 kebeles and found on 1600 to $2400 \mathrm{~m}$ above sea level.

\section{Study Design}

A cross-sectional study was conducted to assess indigenous knowledge of local people on medicinal plants used for livestock treatment.

\section{Site Selection}

For the ethno botanical survey, a total of five selected kebeles (the smallest administrative units in Ethiopia) were selected purposively from the Kersa district based on the availability of transportation and their closeness to Jimma town which are found at an average distance of $8 \mathrm{~km}$ from Jimma town. These kebeles were Merewa, Babo, Kombolcha, Kuja Muja and Ankaso.

\section{Informant Selection}

Selection of informants was performed following Martin (1995) who indicated that when recording indigenous knowledge held by knowledgeably traditional healers or by certain social groups the choice of informant is crucial. According to Storck et al. (1991) the size of the sample depends on the available funds, time and other reasons and not necessarily on the total population. Accordingly, a total of 40 informants $(33$ male and 7 female) 7-9 from each Kebele were selected purposively with the help of Kebele elders and Kebele leader.

\section{Method of Data Collection}

Ethno botanical data were collected through structured questionnaire and field observation. The questionnaire were prepared in English and translated to Afaan Oromoo Language.

\section{Method of Data Analysis}

The collected data were analyzed using Microsoft Office Excel spreadsheet and presented using table, charts and graphs.

\section{RESULTS}

The collected data regarding plant species, parts used, source, preparation method, route of administration, and ways of transferring knowledge and source of healing practice were analyzed and presented as follow:

\section{Socio-demographic Characteristics of the Informants}

In this survey, a total 40 informants of which 33 male and 7 female informants were involved. The age of the informants ranged from 30 to 75 but the majority of the informant's age range from 30 to 50. Regarding the educational status, the majority of the informants were not educated 33 but only 7 have education below grade 9 (Table 1). This shows that even though most of the traditional healers are not educated, they know more about medicinal plant than educated ones as indigenous knowledge on medicinal plants transferred orally and secretly from generation to generation.

\section{Medicinal Plants used for Livestock Treatment}

A total of 33 medicinal plant species belonging to 24 families were reported to be used for treating livestock ailment in the study area. Out of 24 families, the family Fabaceae was represented the highest number of species (4 species, 12.12\%). (Table 2 ).

\section{Source of Medicinal Plants}

Regarding distribution of medicinal plants, out of 33 plant species, $22(66.66 \%)$ were obtained from wild whereas $11(33.33 \%)$ from cultivated (Table $3 \& 7$ ). 
Table 1: Socio-demographic characteristics of the informants

\begin{tabular}{lccccc}
\hline Characteristics & \multicolumn{5}{c}{ Gender } \\
\cline { 2 - 6 } Age & Male & Percentage & Female & Percentage & Total \\
\hline $30-40$ & 10 & 25 & 4 & 10 & 35 \\
$40-50$ & 11 & 27.5 & 3 & 7.5 & 35 \\
$50-60$ & 5 & 12.5 & - & - & 12.5 \\
$60-70$ & 4 & 10 & - & - & 10 \\
$70-75$ & 3 & 7.5 & - & - & 75 \\
Total & 33 & 82.5 & 7 & 17.5 & 100 \\
\hline Educational & Frequency & Percentage & & \\
status & \multicolumn{7}{c}{. } & & & & \\
\hline 0 & 33 & 82.5 & & \\
$1-4$ & 4 & 10 & & & \\
$5-8$ & 3 & 7.5 & & \\
Total & 40 & 100 & & \\
\end{tabular}

Table 2: Medicinal plants families in the study area with the corresponding number of species

\begin{tabular}{lcc}
\hline Family & Number of species & Percentage (\%) \\
\hline Fabaceae & 4 & 12.12 \\
Solanaceae & 2 & 6.06 \\
Rutaceae & 2 & 6.06 \\
Euphorbiaceae & 2 & 6.06 \\
Asteraceae & 2 & 6.06 \\
Cucurbitaceae & 2 & 6.06 \\
Crassulaceae & 1 & 3.03 \\
Cupressaceae & 1 & 3.03 \\
Alliaceae & 2 & 6.06 \\
Brussulaceae & 1 & 3.03 \\
Spindaceae & 1 & 3.03 \\
Compositeae & 1 & 3.03 \\
Miemispermaceae & 1 & 3.03 \\
Phytolaccaceae & 1 & 3.03 \\
Myscinanceae & 1 & 3.03 \\
Oliniaceae & 1 & 3.03 \\
Viscaceae & 1 & 3.03 \\
Myrtaceae & 1 & 3.03 \\
Runanculaceae & 1 & 3.03 \\
Bignoniaceae & 1 & 3.03 \\
Lamiaceae & 1 & 3.03 \\
Moraceae & 1 & 3.03 \\
Piperaceae & 1 & 3.03 \\
Sapindaceae & & 3.03 \\
\hline & &
\end{tabular}

Table 3: Source of Medicinal Plants

\begin{tabular}{lcc}
\hline Source & Frequency & Percentage (\%) \\
\hline Wild & 22 & 66.66 \\
Cultivated & 11 & 33.33 \\
Both cultivated and wild & - & - \\
Total & 33 & 100 \\
\hline
\end{tabular}

\section{Growth Habit of Medicinal Plants}

According to the interview result from the study area, herbs constitute the largest category 13(39.39\%) followed by shrubs $11(33.33 \%)$ trees $7(21.21 \%)$, climber $1(2.56 \%)$ and lianal (2.56\%) (Figure 1; Table 7).

\section{Plant Parts Used}

According to the interview result in the study area, leaves are the most commonly used plants parts accounting for $57.57 \%$

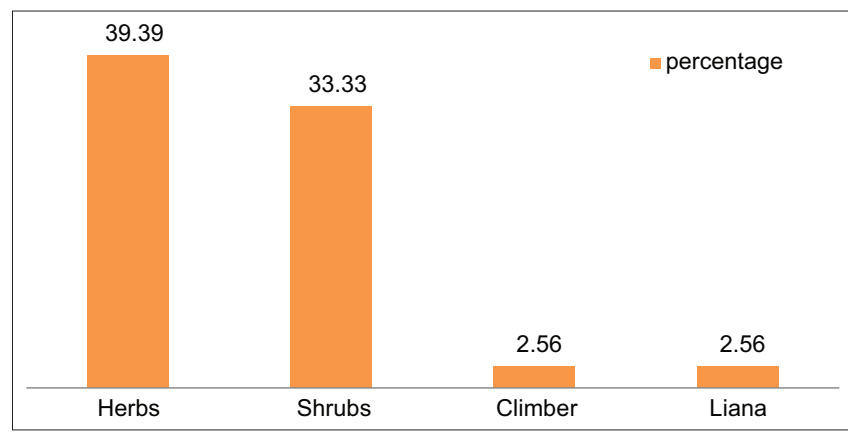

Figure 1: Growth habit of medicinal plants

followed by roots $21.21 \%$, seeds $9.09 \%$, fruits $6.06 \%$, bark $3.03 \%$ and bulb $3.03 \%$ (Figure 2; Table 7).

\section{Method of Preparation}

According to the interview result in the study area, pounding was the most commonly used method of preparation which accounts $48.48 \%$ followed by crushing $33.33 \%$, powdering $12.12 \%$, pulverization $3.03 \%$ and concoction $3.03 \%$ (Figure 3 ; Table 7 ).

\section{Routes of Administration}

The major route of administration in the study area was oral $78.78 \%$ followed by dermal $9.09 \%$, both nasal- oral $6.06 \%$ and oral-dermal 6.06\% (Table 4; Table 7).

\section{Sources of Healing Knowledge}

According to the interview result, most of the traditional healers of the study area reported the highest and most commonly cited sources of healing was from father mother, which accounts $7.5 \%$ (30) followed by wife husband $17.5 \%$ (7) and other neighborhoods $7.5 \%$ (3) (Table 5.2).

\section{Transferring Knowledge of Traditional Medicinal Plants}

The informants from the study area reported that the highest number for the ways of transferring knowledge on traditional medicinal plants is to eldest son 19(47.5) followed by all children of the family $15(37.5 \%)$ and eldest daughter 6(15\%) (Table 6).

\section{DISCUSSION}

In this study, a total 40 traditional healers of which $82.5 \%$ (33), male and $17.5 \%$ (7) female respondents were involved. The age of the respondents ranged from 30 to 75 , the majority of the traditional healers were not educated $33(82.5 \%)$ but only $7(17.5 \%)$ have education below grade 8 . This shows that even though most of the traditional healers were not educated, the know more about medicinal plants than educated ones as indigenous knowledge on medicinal plants transferred orally and secretly from generation to generation.

The results of this study revealed 33 medicinal plant species belonging to 24 families used to treat 13 livestock ailments in the 


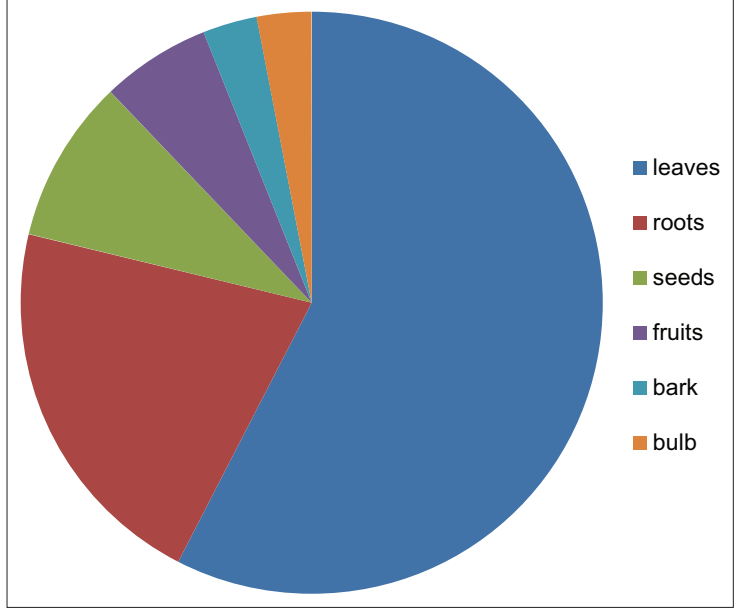

Figure 2: Plant parts used

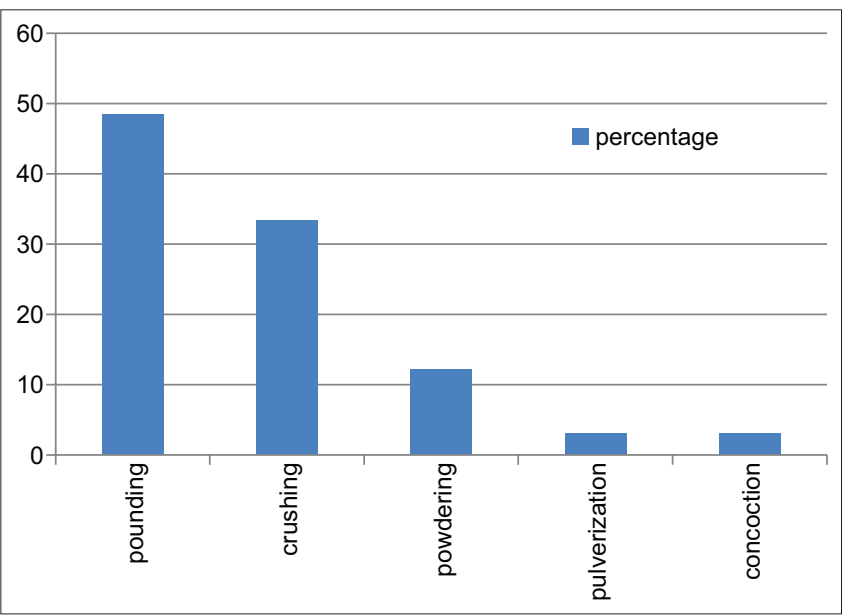

Figure 3: Method of remedies preparation

Table 4: Routes of administration

\begin{tabular}{lcc}
\hline Route of administration & Frequency & Percentage (\%) \\
\hline Oral & 26 & 78.78 \\
Nasal-oral & 2 & 6.06 \\
Dermal & 3 & 9.09 \\
Dermal-oral & 2 & 6.06 \\
Total & 33 & 100 \\
\hline
\end{tabular}

Table 5: Sources of healing knowledge

\begin{tabular}{lcc}
\hline Source & Frequency & Percentage (\%) \\
\hline Father & 30 & 75 \\
Wife/husband & 7 & 17.5 \\
Sister/brother & - & - \\
Other neighborhood & 3 & 7.5 \\
Total & 40 & 100 \\
\hline
\end{tabular}

Table 6: Transferring knowledge of traditional medicinal plants

\begin{tabular}{lcc}
\hline To whom transferred & Frequency & Percentage (\%) \\
\hline Eldest soon & 19 & 47.5 \\
Eldest daughter & 6 & 15 \\
All children of the family & 15 & 37.5 \\
Total & 40 & 100 \\
\hline
\end{tabular}

study area. The family Fabaceae was represented by the highest number of species 4(12.12\%) followed by Solonaceae, Rutaceae, Euphorbiaceae, Asteraceae, Cucurbitaceae, Alliaceae, each represents 2 species (6.06\%). Each of the remaining 17 families had single species represent actives. This finding is comparable with the results of Megersa (2010) study conducted in Wayu Tuka Woreda who showed that Fabaceae was the leading family in the study area.

Out of 33 identified medicinal plant species, $21(63.63 \%)$ were obtained from wild followed by domesticated $12(36.36 \%)$. Similar study conducted by Giday et al. (2003) from Zay people in Ethiopia indicates harvesting of $82 \%$ medicinal plants from the wild. According to Megersa (2010) Wayu Tuka Wored revealed that large numbers of medicinal plants are collected from wild areas. This shows wild habitats are subjected to the loss of number of species due to anthropogenic factors such as fire wood, agricultural expansion, drought and other. Analysis of growth habits revealed that herbs and shrubs constitute the largest category with the proportion of $39.39 \%$ and $33.33 \%$ respectively followed by trees $21.21 \%$, climber $2.56 \%$ and liana $2.56 \%$.

The most commonly used plant parts for remedies preparation in the study area were leaves $57.7 \%$ followed by roots $21.21 \%$, seeds $9.09 \%$, fruits $6.06 \%$, bark $3.03 \%$ and bulb3.03\%. This findings is in line with the results of Tamene et al. (2000) study conducted in Cheffa showed that the highest plant parts used for preparation of remedies is leaf $(56.89 \%)$. The methods of remedies preparation commonly used were pounding and crushing with the proportion of $(42.42 \%)$ and $(30.3 \%)$ respectively, followed by powdering $(21.21 \%)$, concoction $(3.03 \%)$ and pulverization $(3.03 \%)$. This finding is also in agreement with the results of Tamene et al. (2000), in Cheffa who revealed that pounding, crushing and squeezing $(88.88 \%)$ are the most commonly used mode of preparation. The route of administration commonly used in the study area were oral constituting the largest category of $78.78 \%$ followed by dermal $9.09 \%$, both nasal-dermal $6.06 \%$ and oral -dermal6.06\%. This is parallel with the results of Sori et al. (2004), in Borena who revealed that oral $(54 \%)$ followed by topical $(4 \%)$ are the main route of administration.

The finding of the study with regard to the source of healing knowledge showed that $(75 \%)$ of healers acquired their knowledge and experience from their parent (Fathers/Mothers) followed by wife/husband (17.5\%) and other neighborhoods (7.5\%). In line with this study, the results of Abdurhaman (2010) in Ofla Woreda showed that the highest number for traditional medicinal plant knowledge gain is from father/mother $40(47.66 \%)$. Analysis of data from this study indicated that knowledge and practices on medicinal plants reside with few families. This finding agrees with the results of Abdurrahman (2010) who showed that the highest number for the ways of transferring knowledge on medicinal plants is to eldest son $25(29.6 \%)$. The secrecies of more knowledge and practices with less people could be series for the sustainability and continuity of traditional knowledge of medicinal plants. 
Table 7: Medicinal plants used for treatment of livestock disease, scientific name, vernacular names, parts used, preparation method, disease treated and administration route

\begin{tabular}{|c|c|c|c|c|c|c|c|}
\hline S.No & $\begin{array}{l}\text { Vernacular } \\
\text { name }\end{array}$ & Scientific name & Family name & $\begin{array}{l}\text { Plant } \\
\text { collection }\end{array}$ & $\begin{array}{l}\text { Plant parts used and preparation } \\
\text { method }\end{array}$ & $\begin{array}{l}\text { Route of } \\
\text { administration }\end{array}$ & $\begin{array}{l}\text { Disease } \\
\text { treated }\end{array}$ \\
\hline 1 & Andoodee & $\begin{array}{l}\text { Phytolacca } \\
\text { dodecandra }\end{array}$ & Phytolaccaceae & w & Leaf concoction is drunk & Oral & Rabies \\
\hline 2 & Abasuuda & Nigella Sativa & Runancculaceae & D & $\begin{array}{l}\text { Seed is powdered, mixed with water and } \\
\text { given to cattle }\end{array}$ & Oral & Stomachache \\
\hline 3 & Bakkanniisa & $\begin{array}{l}\text { Croton } \\
\text { macrostachyus }\end{array}$ & Euphorbiaceae & W & $\begin{array}{l}\text { Leaves crushed, and rubbed on infected } \\
\text { part }\end{array}$ & $\begin{array}{l}\text {-oral } \\
\text {-Dermal }\end{array}$ & $\begin{array}{l}\text { Bloating } \\
\text { Scabies }\end{array}$ \\
\hline 4 & $\begin{array}{l}\text { Baargamoo } \\
\text { adii }\end{array}$ & $\begin{array}{l}\text { Eucalyptus } \\
\text { globulus }\end{array}$ & Myrtaceae & D & Leaf is pounded, boiled and drunk & Oral & Cough \\
\hline 5 & Bosoqqee & $\begin{array}{l}\text { Kalanchoe } \\
\text { petitiana }\end{array}$ & Crassulaceae & W & $\begin{array}{l}\text { Root is pounded and given to } \\
\text { affected cattle }\end{array}$ & Oral & Blackleg \\
\hline 6 & Ceekaa & Calpurniaurea & Fabaceae & W & $\begin{array}{l}\text { Leaves are pounded and used to } \\
\text { wash scabies }\end{array}$ & Dermal & Scabies \\
\hline 7 & Burii & Impatiens rothii & Miemispanceae & $\mathrm{D}$ & Fresh leaf is crushed and given to cattle & Oral & Bloating \\
\hline 8 & Dambii & $\begin{array}{l}\text { Ficusthonningi } \\
\text { blume }\end{array}$ & Moraceae & W & $\begin{array}{l}\text { Leaves are pounded and mixed with salt } \\
\text { and given to cattle }\end{array}$ & Oral & Blackleg \\
\hline 9 & Dichoo & Civisium vulgare & Asteraceae & W & Root is pounded and given to cattle & Oral & Diarrhea \\
\hline 10 & Eebicha & Ver amygdalina & Asteraceae & W & $\begin{array}{l}\text { Leaves crushed, socked in water ad given } \\
\text { to cattle }\end{array}$ & Oral & Blackleg \\
\hline 11 & Faca'aa & Cucumis ficifolius & Cucurbitaceae & W & $\begin{array}{l}\text { The root and leaf pounded, mixed with } \\
\text { salt and water then given to cattle }\end{array}$ & Oral & Blackleg \\
\hline 12 & Botoroo & $\begin{array}{l}\text { Stereospermum } \\
\text { kunthianumcham }\end{array}$ & Bignoniaceae & W & $\begin{array}{l}\text { Barks pounded, mixed with water } \\
\text { and drunk }\end{array}$ & Oral & Snakebite \\
\hline 13 & Gaattiraa & Juniperus procera & Cupressaceae & $\mathrm{D}$ & $\begin{array}{l}\text { Leaves crushed,mixed with water and } \\
\text { given to cattl }\end{array}$ & Oral & $\begin{array}{l}\text { Abdominal } \\
\text { pain }\end{array}$ \\
\hline 14 & $\begin{array}{l}\text { Gurra } \\
\text { hantuutaa }\end{array}$ & Vigna vexillata & Fabaceae & W & Leaves cushed and rubbed on affected part & Dermal & $\begin{array}{l}\text { Spider } \\
\text { poison }\end{array}$ \\
\hline 15 & Gursadii & $\begin{array}{l}\text { Allophyllus } \\
\text { macrobotryolsoile }\end{array}$ & Sapindaceae & W & $\begin{array}{l}\text { Fresh leaves are crushed, mixed with } \\
\text { water and given to cattle }\end{array}$ & Oral & $\begin{array}{l}\text { Internal } \\
\text { parasite }\end{array}$ \\
\hline 16 & Harmoo & $\begin{array}{l}\text { Viscum } \\
\text { tuberculatum }\end{array}$ & Viscaceae & W & Leaf is pulverized and given to cattle & Oral & Blackleg \\
\hline 17 & $\begin{array}{l}\text { Hidda } \\
\text { hantuutaa }\end{array}$ & $\begin{array}{l}\text { Vigna } \\
\text { membraceae }\end{array}$ & Fabaceae & W & $\begin{array}{l}\text { Leaves are pounded, dried, mixed with } \\
\text { water and given to cattle }\end{array}$ & Oral & Epilepsy \\
\hline 18 & Ittacha & $\begin{array}{l}\text { Dodonaceae } \\
\text { angustifolia }\end{array}$ & Spindaceae & W & $\begin{array}{l}\text { Fresh leaves are crushed with water } \\
\text { added and given to cattle }\end{array}$ & Oral & Diarrhea \\
\hline 19 & Haanquu & $\begin{array}{l}\text { Embelia } \\
\text { schimperi }\end{array}$ & Myscinanceae & W & $\begin{array}{l}\text { Leaves are pounded, mixed with salt and } \\
\text { water and given to cattle }\end{array}$ & Oral & Blackleg \\
\hline 20 & Loomii & Citrus lemon & Rutaceae & C & Fresh paste is crushed and poured & $\begin{array}{l}\text { Oral } \\
\text { Dermal }\end{array}$ & $\begin{array}{l}\text { Tick } \\
\text { infestation }\end{array}$ \\
\hline 21 & Maraarrisa & $\begin{array}{l}\text { Clerodendron } \\
\text { mycricoides }\end{array}$ & Lamiaceae & W & Root is pounded & Oral & Diarrhea \\
\hline 22 & $\begin{array}{l}\text { Minaan } \\
\text { bofaa }\end{array}$ & $\begin{array}{l}\text { Momordica } \\
\text { foetida schumach }\end{array}$ & Cucurbitaceae & W & $\begin{array}{l}\text { Root is pounded,mixed with water and } \\
\text { gien to cattle }\end{array}$ & $\begin{array}{l}\text { Nasal } \\
\text { Oral }\end{array}$ & $\begin{array}{l}\text { Abdominal } \\
\text { colic }\end{array}$ \\
\hline 23 & Noolee & Olinia rochetiana & Oliniaceae & W & $\begin{array}{l}\text { Leaf is crushed,mixed with salt and gien } \\
\text { to cattle }\end{array}$ & Oral & $\begin{array}{l}\text { Internal } \\
\text { parasite }\end{array}$ \\
\hline 24 & Mimmixa & Capsicum annum & Solanaceae & $\mathrm{D}$ & $\begin{array}{l}\text { Fruit is powdered, mixed with water and } \\
\text { given to cattle }\end{array}$ & Oral & Bloating \\
\hline 25 & Qullubbii adii & Allium sativum & Alliaceae & $\mathrm{D}$ & Bulbs are pounded and given to cattle & Oral & Blackleg \\
\hline 26 & Sanaamakii & $\begin{array}{l}\text { Sennadidy } \\
\text { mobotrya }\end{array}$ & Fabaceae & W & Leaves are pounded and given to cattle & Oral & Blackleg \\
\hline 27 & Shinfaa & Lepidium sativum & Brassicaceae & D & $\begin{array}{l}\text { Seed is powdered, mixed with salt and } \\
\text { given to cattle }\end{array}$ & Oral & Bloating \\
\hline 28 & Sigiluu & Fagaropsis & Rutaceae & W & $\begin{array}{l}\text { Fresh leaves are crushed, mixed with } \\
\text { water and given to cattle }\end{array}$ & Oral & Blackleg \\
\hline 29 & Qabarichoo & $\begin{array}{l}\text { Echinops } \\
\text { kebericho mesfin }\end{array}$ & Compositeae & W & $\begin{array}{l}\text { Root pounded, mixed with water and } \\
\text { given to cattle }\end{array}$ & Oral & Blackleg \\
\hline 30 & Qobboo & $\begin{array}{l}\text { Ricinus } \\
\text { communis }\end{array}$ & Euphoriaceae & D & $\begin{array}{l}\text { Leaves pounded, mixed with water and } \\
\text { given to cattle }\end{array}$ & Oral & Blackleg \\
\hline 31 & Tamboo & $\begin{array}{l}\text { Nicoticam } \\
\text { tabacum }\end{array}$ & Solanaceae & $\mathrm{D}$ & Leaves are crushed,soaked in water & $\begin{array}{l}\text { Oral } \\
\text { Nasal }\end{array}$ & $\begin{array}{l}\text { Leech } \\
\text { Blackleg }\end{array}$ \\
\hline 32 & Tunjoo & Piper capense & Piperaceae & W & Root is pounded and given to cattle & Oral & Leech \\
\hline 33 & Sunqoo & Allucepal & Alliaceae & $\mathrm{D}$ & Seed is powdered, mixed with water & Oral & Stomachache \\
\hline
\end{tabular}




\section{CONCLUSION}

This study revealed 33 medicinal plant species used for livestock treatment. Majority of the reported medicinal plant species were from wild habitat. Leaves are harvested for medicinal purpose than other plant parts in the study area. Herbs and shrubs are highly utilized for medicinal purpose than others. Pounding and crushing are the most frequently used method of traditional medicine preparation. Most of the medicinal plants were administered orally. Most of the knowledge on herbal remedies in this study area acquired from the parents (fathers/mothers). The highest number for ways of transferring knowledge on traditional plants is to the eldest son.

\section{REFERENCES}

Abdurhatman, N. (2010). Ethno botanical study of medicinal plants used by local people n Ofla Wereda, Southern Zoe of Tigray Region, and Ethiopa. M.Sc. Thesis Addis Ababa University.

Abebe, D. (2001). The role of medicinal plants in healthcare coverage of Ethiopia, the possible integration. In M. Zewdu, A. Demissie, (Eds.), Conservation and sustainable use of medicinal plants in Ethiopia proceeding of the national workshop on biodiversity conservation and sustainable use of medicinal plants in Ethiopia (pp.6-21), IBC, Addis Ababa.

Central Statistical Authority (CSA) (February 2006/7). Agric sample survey report on livestock and livestock characteristics.volume 11 Addis Ababa, Ethiopia.

Getachew, B., \& Shifera, D. (2002).medicinal plants in Bonga forest and their uses. Biodiversity new slett. 1:9-10 IBCR, Addis Ababa.

Giday, M., \& Ameni, G. (2003). An ethno botanical survey on plants of veterinary importance in two Weredas of Southern Tigray, Northern Ethiopia. SINET Ethiopia Journal of Science, 20(2), 123-136

Giday, M., Asfaw, Z., \& Woldu, Z. (2009). Medicinal plants of the Meinit ethnic group of Ethiopia: an ethnobotanical study. Journal of Ethnopharmacology, 124(3), 513-521. https://doi.org/10.1016/j. jep.2009.05.009

Harun-or-Rashid, M., Tanzin, R., Ghosh, K. C., Jahan, R., Khatun, M. A., \& Rahmatullah, M. (2010). An ethno veterinary survey of medicinal plants used to treat cattle diseases in Birishiriarea, Netrakona Distirict, Bangladesh. Advances in Natural and Applied Sciences, 4(1), 10-13.

Kalayou, S., Haileselassie, M., Gebre-Egziabher, G., Tiku'e, T., Sahle, S., Taddele, H., \& Ghezu, M. (2012). In-vitro antimicrobial activity screening of some ethnoveterinary medicinal plants traditionally used against mastitis, wound and gastrointestinal tract complication in Tigray Region, Ethiopia. Asian Pacific Journal of Tropical Biomedicine, 2(7), 516-522. https://doi.org/10.1016/S22211691(12)60088-4
Kokwaros J. O. (1976). Medicinal plants of East Africa, General printers LTD. Homabay Nairobi, Kenya

Lulekal, E., Kelbessa, E., Bekele, T., \& Yineger, H. (2008). An ethnobotanical study of medicinal plants in Mana Angetu district, southeastern Ethiopia. Journal of Ethnobiology and Ethnomedicine, 4, 10. https:// doi.org/10.1186/1746-4269-4-10

McCorkle, C. (1995). Back to the future: Lessons from ethnoveterinary RD \& E for studying and applying local knowledge, Agriculture and Human Values. The Agriculture, Food, \& Human Values Society, 12(2), 52-80. https://doi.org/10.1007/BF02217297

Megersa, M. (2010). Ethno botanical study of medicinal plants in Wayu Tuka Wereda, East Wollega Zone of Oromia Region, Ethiopia, Unpublished M.SC.

Rukangira, E., (2001). The African herbal industry. Constraints and challenges. In proceedings of the natural products and cosmeceuticals conference. Erboristeria Domani. 1-23.

Sinha, P., Govil, N. J, \& Singh, V. K. (2002). Diseases and their management, recent progress in medicinal plants. Sctech, public, USA.PP.1-105

Sori, T., Bekana, M., Adugna, G., \& Kelbessa, E. (2004). Medicinal plants in ethno veterinary practices of Borana pastoralists, Southern Ethiopia. International Journal of Applied Research in Veterinary Medicine, 2, 220-225

Storck, H., Bezabih, E., Berhanu, A., Borowieck, A., \& Shimalis,W. (1991). Farming systems and farm management practices of small holders in the Hararghe highlands. Farming systems and resource economics in the tropics, Vol.11.Wissenschaft Surlang vauk.Kiel, Germany.

Tabuti, J. R., Dhillion, S. S., \& Lye, K. A. (2003). Ethnoveterinary medicines for cattle (Bos indicus) in Bulamogi county, Uganda: plant species and mode of use. Journal of Ethnopharmacology, 88(2-3), 279-286. https://doi.org/10.1016/s0378-8741(03)00265-4

Tadeg, H., Mohammed, E., Asres, K., \& Gebre-Mariam, T. (2005) Antimicrobial activities of some selected traditional Ethiopian medicinal plants used in the treatment of skin disorders. Journal of Ethnopharmacology, 100(1-2), 168-175. https://doi.org/10.1016/j. jep.2005.02.031

Tamene, B., Bekele, T., \& Kelbesa, E. (2000). An ethnobotanical study of the semi-wetland vegetation of Chefa, Ethiopia. Master Thesis. Addis Ababa University, Addis Ababa, Ethiopia.

Teklehaymanot, T., \& Giday, M. (2007). Ethnobotanical study of medicinal plants used by people in Zegie Peninsula, Northwestern Ethiopia. Journal of ethnobiology and ethnomedicine, 3, 12. https:// doi.org/10.1186/1746-4269-3-12

Yirga C, Hassen M (2000). C rop-Livestock Farming System in the Highland of Ethiopia: Smallholder Farmers Management Practice and Constraints In: Wheat and Weeds; Food and Feeds Processing of Two Stakeholder Workshop. Improving The Production of CropLivestock Production in Wheat Based Farming System in Ethiopia. Addis Ababa, Ethiopia

Yirga, G. (2006). Use of traditional medicinal plants by indigenous people in Mekelle town, capital city of Tigray regional state of Ethiopia. Journal of Medicinal Plants Research, 4(17), 1799-1804. 